\title{
Trademark Protection: Bangladesh Approach
}

\author{
Md. Milan Hossain \\ Senior Lecturer (PhD Fellow, Jhangirnagar University, Savar, Dhaka), Department of Law, Northern \\ University Bangladesh (NUB, Holding No-13, Road No-17, Banani C/A, Dhaka-1213),Bangladesh,
}

\begin{abstract}
A trademark is a legal protected name, sign or symbol which is an integral part in case of industry; it distinguishes the goods of one enterprise from another. In a country, trademark protection rights can be established through registration or use or both. In Bangladesh, trademark registration is not compulsory but in practice, no trademark is generally entitled to get protection from the law of court without registration; a certificate of a registered trademark from a proper government authority is deemed as a prima facie evidence. This paper focuses on trademark, trademark protection and it's obtaining procedure in Bangladesh; legal remedies in case of infringement. This article also shows the standard of trademark protection, existing problems in case of implementation of present trademark laws and paves the ways.
\end{abstract}

Keywords: Trademark, Trademark Protection, Registration, Passing off, Infringement, Remedies.

\section{Introduction}

Trademark requires statutory protection to ensure exclusive right to the proprietors. It is also necessary for smooth industrial and economical development of a country. In Bangladesh, the Trademark Act 2009 provides protection to the trademark proprietors. The Trademark Rules 1963 is also operative here which is very poor statutory support in case of ensuring trademark protection with compliance international treaty. Therefore, the present laws fail to fulfill the demands of present digital based society. This paper focuses the present situation of trademark protection in Bangladesh; it also determines whether the existing trademark laws provide standard protection to the proprietor of trademarks or service marks; it also highlights the drawbacks of the existing laws and gives the ways to remove them.

\section{I.I Definition of Trademark}

Trademark is a symbol or sign which indicates the source of goods; it distinguishes the goods or services of one entrepreneur from another. Under the Trade Mark Act, 2009, "Trademark" means a registered trade mark or a mark used in relation to goods or service or a mark used or proposed to be used in relation to any service or goods indicating a connection in the course of trade between the goods and the person having the right, either as proprietor or as registered user, to use the mark (Section 2(8)). In Bangladesh, the term 'trademark' includes service mark too (section 2(8) (a) (ii).

\section{I.II Historical Background}

Bangladesh gains its independence in 1971 thorough a liberation war with West Pakistan. Prior to 1947, it was the part of Indian subcontinent under the British Regime and British Rules were applicable in most cases or they passed new enactments for the subcontinent. There were no specific enactments in British India before 1889. At that time, trademark protection was ensured under the different enactments like the Penal Code 1860, the Specific Relief Act, 1877. In 1889, the then British rulers first enacted the Merchandise Marks Act, 1889 and the Trade Marks Act, 1940 for protecting the trademarks. The Act of 1940 was enacted in British-India by following the Trade Mark Act, 1938 of England.

Bangladesh inherited the Merchandise Marks Act, 1889 and the Trade Marks Act, 1940 from Pakistan by the independence of 1971. These two laws had ensured trademarks protection in Bangladesh for long time. In 2008, both, the Merchandise Marks Act, 1889 and the Trade Marks Act, 1940 were repealed by the Trademark Ordinance, 2008 but this law was also repealed by the Trademarks Act, 2009. The present legal basis of trade mark protection in Bangladesh is the Trademark Act of 2009 (herein referred to as the 2009 Act) and Trademark Rules 1963. Bangladesh is also a signatory to the following international agreements:

- The World Intellectual Property Organization, since May 1985 (herein referred to as WIPO)

- The Paris Convention for the Protection of Industrial Property, since March 1991(herein referred to as Paris Convention)

- The Agreement on Trade-Related Aspects of Intellectual Property Rights, since January 1995(herein referred to as TRIPS Agreement) 
Bangladesh follows the international classification of goods and services under the Nice Agreement (Ninth Edition). Here the classes of goods and services 01- 45 are in force. The registration of Service Marks System has been included in the Act, 2009 vide S. R. O. No.211-Law/2008 dated June 30, 2008, w.e.f July 01, 2008. At present, any person claiming to be the proprietor of a service mark may file an application for registration of any service mark under class-35 to 45 .

In Bangladesh, the Department of Patents, Designs \& Trademarks is the administrative authority under the Ministry of Industries deals with the trademark \& service mark registration etc. The Head Office of Trademarks Registry is in Dhaka (91, Motijheel C/A ( $5^{\text {th }}$ Floor), Dhaka-1000). A regional office relating to Trademarks is in Chittagong.

\section{I.III Trademark Protection by Registration}

Trademark protection right is an indispensable right to trademark proprietor. It must be ensured for a smooth industrial development and to earn profit by using it. It claims exclusive rights. According to Article 16.1 of the TRIPS Agreement, the owner of a registered trademark must be granted an exclusive right to prevent all third parties not having the owner's consent from using in the course of trade identical or similar signs for goods or services which are identical or similar to those in respect of which the trademark is registered if such use would result in a likelihood of confusion. In the case of use of identical sign for identical goods or services, a likelihood of confusion must be presumed.

In Bangladesh trademark protection is ensured to the trademark proprietor by registration. Any other person than a registered proprietor, can get trade protection as registered users, or by grant of license, or by means of assignment or transmission. Here the provisions of infringement and falsification of trademarks also play an important role in providing trademark protection to the trademark owners.

The law relating to trademarks is against trafficking in trademarks. Certain marks and brands qualify (by virtue of their extensive use and popularity) to be known as well-known marks. Articles 16.2 and 16.3 of the TRIPS Agreement require protection to the well-known marks. Under the 2009 Act, well known mark (even unregistered) also gets protection.

\section{I.IV Conditions of Trademark Registration}

In order to get trademark registration, a mark must be inherently distinctive or distinctive through use. An arbitrary marks (apple for computer), fanciful mark (KODAK) or suggestive mark (FRIDGEDAIRE as applied to refrigerators) etc are treated as distinctive mark. Actually any sign capable of distinguishing the goods or services of one undertaking from those of other undertakings (thus including service marks) shall be eligible for getting registered as a trademark. (TRIPS Agreement, Art. 15.1). In Bangladesh the basic requirements of a mark to be registered are maintained with the compliance of International Treaties like Paris convention or TRIPS Agreement. Besides, the following mark or part of mark shall not be registered as a trademark-

i) which comprises or consists of any scandalous or obscene matter;

ii) the use of which would be contrary to any law for the time being enforce;

iii) the use of which would be likely to deceive or cause confusion; or

iv) which contains any matter likely to hurt the religious susceptibilities of any classes of the citizen of Bangladesh;

v) which is identical with, or is an imitation of, or contains as an element, an armorial bearing, flag or other emblem, a name or abbreviation or initials of the name of, or official sign or hallmarked adopted by, any state or international organization created by an international convention, charter or other instruments (the 2009 Act, section 8).

No trademark shall be registered in respect of any goods or services if it is identical with or confusingly similar to, or constitutes a translation or a mark trade description which is well-known in Bangladesh (for example TATA mark well-known in Bangladesh) for identical or similar goods or services of another enterprise (the Act, 2009, section 10(4)).

\section{I.V Trademark Registration Process}

Any person claiming to be the proprietor of a Trade Mark or Service Mark used or proposed to be used by him or them, who desire to register, he shall apply in writing to the Registrar in the prescribed manner for the registration of his trademark or service mark (the 2009 Act, sec. 15). Separate application is required for every class of goods or services. Every application made under section 15 of the Act may be submitted to the Head Office of the Department or any branch of the Trademarks Registry having jurisdiction over the principal place of business in Bangladesh of the applicant or, in case of the joint applicants, the principal place of business in 
Bangladesh, whose name is first mentioned in the application, as having a place of business in Bangladesh is situated.

At the time of filing an application for the purpose of registration of a mark in Bangladesh the following documents or information will be required:-

(i) Description of the Trademark or service mark and if it is a logo or device mark then 15 (fifteen) copies label or logo for each of the application.

(ii) Full Name, Street Address and Nationality of the applicant(s): In the case of a company, the country or state of incorporation and the address of the principle place of business should be given. In the case of a partnership firm, full names of all partners and the name of the partnership is required.

(iii) Status of the Applicant: Whether the applicant is a 'manufacturer' or 'merchant' or 'manufacturer \& merchant' etc should be mentioned.

(iv) Description of goods or service for which the mark is to be registered.

(v)The date of use of the Trademark in Bangladesh (if any), it may be used or proposed to be used also.

(vi) Whether the mark is being used in Bangladesh by the proprietors, or proposed to be used in Bangladesh by the proprietors, or proposed to be used by a body corporate to be constituted, or proposed to be used in Bangladesh by a registered user (in which case an application for registration of registered user must be filed simultaneously).

(vii) A duly executed Power of Attorney or authorization (Form TM-48): It should be signed by applicant (if individual) or by an officer of the applicant company, whose position in the company should be stated including the corporate seal. It is not necessary to notarize or legalize the authorization.

(viii) Prescribed application fee (USD. 300\$).

It is pertinent to mention that International priority is available in Bangladesh under the Paris Convention. It is possible to claim partial priority within Bangladesh. The Priority must be claimed at the time of filing the application for registration and the following must be provided:

(i) Name of the country from which the priority arises

(ii) Priority application number and date

(iii) A certified copy of the Convention Application from which the priority is claimed must be filed within a period of six (6) months of the filing date of the application in Bangladesh.

After filing the application it will take two to seven days for obtaining the Trade Mark Number and acknowledgement receipt from the date of filing of the application. Then other formalities like advertisement in the journal and opposition procedure are conducted by the supervision of the authority.

When a Trade Mark has been accepted and duly published in the Journal and if no opposition is lodged by anybody within 60(sixty) days from the date of publication of the Journal, or if the opposition is decided in favor of the applicant, then the application will be qualified for registration under the provision of section 20 of the Act, 2009 and thereafter the applicant is to submit registration fees to obtain the registration certificate. It is pertain to mention that trademark application fee, opposition fee or registration fee are to be paid separately in Bangladesh. After registration, the registrar will issue a certificate of registration. Upon registration, the effective date is the filing date of the application. In case of a priority claim, the date of registration is deemed the earlier filing date in the Paris Convention country from which the priority is being claimed.

By virtue of registration the registered proprietor is entitled to protection in the court of justice in respect of infringement of his/their registered Trade Mark or Service Mark under section 24(1) of the 2009 Act. The duration of protection of a registered mark extends to seven years but is not limited in time; it can be renewed for further period of every 10 (ten) years unlimited times.

After registration of any of the mark in Bangladesh there is a provision for cancellation or removal of registration from the register as per the provision of section 42 and 51 of the 2009 Act. Any person who is aggrieved within the meaning of section 42 and 51 of the Act, 2009 may file rectification case in the prescribed manner against the impugned registered Trade Mark either before the Registrar of Trade Marks or before the Hon'ble High Court Division of the Supreme Court of Bangladesh to vary or cancel the registration of the same.

\section{Passing Off And Protection Of Unregistered Trademark}

In Bangladesh, unregistered trademarks or service marks having reputation or well known to the people through the use can get protection in case of passing off (the 2009 Act, sec.24 (2). Passing off is a common law concept. It refers to the misrepresentation of the goods or services of one which is offering as coming from another party. This false impression is created through use of another provider's recognizable trademark, either by the production of an identical copy, or a closely comparable mark.

The passing off action depends upon the principle that nobody has a right to represent his goods as the goods of another. In other words, a man is not entitled to sell his goods or services under the pretence that they 
are those of another person. Passing off occurs when one trader attempts to pass off his goods by misrepresenting them so as to make the consumers believe that his goods are the same as those of another trader. For example, using a mark 'Rata' on a shoe creates a belief that it is a 'Bata' one.

Passing off is not defined in the 2009 Act. It is referred to in sections 24(2), 96(4), and 97 of the Act. Section 24(2) states that the rights of action shall not be affected against any person for passing off goods or services as the goods or services of another person or the remedies in respect thereof. Any proprietor of a trademark, registered or unregistered, can bring an action against any person for passing off his goods or services; he is entitled to remedies thereof; he can get damages or an injunction or an order for delivery-up of infringing labels and marks for destruction or erasure as relief.

Section 96(d) provides that a suit for passing off arising out of the use by the defendant of any trademark which is identical with, or, deceptively similar to, the plaintiff's trademark, whether registered or unregistered, shall be instituted in any court not inferior to a District Court having jurisdiction to try the suit.

\section{Application Of Principle Of National Treatment, Priority And Cross Border Reputation In Bangladesh}

National treatment means that, as regards the protection of industrial property, each country party to Paris Convention or TRIPS Agreement must grant the same protection to nationals of the other member countries as per Articles 2 and 3 of the Paris Convention and article 3.1 of the TRIPS Agreement, 1994. In compliance with these international agreements Bangladesh also provides the same protection to the member countries of the Paris Convention and TRIPS Agreements (the 2009 Act, sec.119). At the same way, the principle of priority is also recognized here under sec. 120 of the Act, 2009. As a result, anyone who registers his mark in a member country other than Bangladesh of Paris Convention or of World Trade Organization, can get protection from the same date in Bangladesh if he makes an application for registration in Bangladesh within 6 (six) months from the date of first registration of the member country.

Reputation of a trademark is an asset to its proprietor; it is significant to get protection; in order to get the protection of trademark in countries other than the origin, that trademark must have a reputation and goodwill. A trademark though not registered or the goods or services carrying such trademark are not used in a country, it may be known well to its citizens by the advertisement through satellite TV, internet, and cinemas, national or international magazines. It is now settled principle that a trademark proprietor having cross-border reputation, can bring an action against any person for unauthorized used of his mark with new goods or similar goods, even though it is not registered or the goods attaching such mark is not used in such a country.

The principle of cross-border reputation hails well known trade marks. International Agreements like the Paris Convention and TRIPS Agreement recognize the protection of well known trademark. Article 6bis of the Paris Convention obliges a member country to refuse or cancel the registration and to prohibit the use of a trademark that is liable to create confusion with another trademark already well-known in that member country for identical or similar goods. Article 16.2 and 16.3 of the TRIPS Agreement provide certain rights for the owners of well-known trademarks and service marks. They extend the protection of Article 6bis of the Paris Convention by including service marks and dissimilar goods. At present, legal protection of well known trade marks are clearly well-established in the jurisdiction of trademarks.

Bangladesh is a signatory to the Paris Convention and TRIPS Agreement. Here the principle of crossborder reputation and national treatment is followed. The rule of cross-border reputation is contained under section 31 of the 2009 Act and it guarantees protection to the well-known trademarks or foreign trade marks on the basis of their international reputation, thereby abiding the requisite of Article 16 of TRIPS Agreement, which grants better protection and treatment of trademarks. As a result, a foreign trade mark owner having cross-border reputation can bring a passing off action in Bangladesh if his mark is unauthorized used in here. In the case of Sunil Kumar Das vs Canon kabushiki kasha, 57 DLR, 2005, pp 93-100, it was also held that wellknown international trademarks had been protected in Bangladesh even when they were not registered in Bangladesh.

However, it is pertinent for overseas traders who hold such marks to act proactively for implementing their goodwill internationally established through their products by registration of those trademarks and instituting timely action and suitable proceedings for enforcing the same.

\section{Trademark Infringement}

Infringement is an unauthorized use of a registered trademark. Without the consent or authorization of the owner if any one uses the registered mark commits infringement. Further use of a similar mark to the registered mark does also constitute infringement of the registered mark.

The 2009 Act gives the registered proprietor of a trademark in respect of any goods the exclusive right to the use of trademark in relation to those goods. That right is deemed to be infringed by any person who, not being the registered proprietor of the trademark or a registered user thereof using by way of permitted use. 
Following are the circumstances under which a person is deemed to have infringed a registered trademark (the 2009 Act, sec.26):

1. Where a person uses a trademark which is identical or similar to the registered trademark used in the course of trade for the similar goods or services not being a 'registered proprietor' or 'permitted user' and cause confusion on the part of the public.

2. Where the registered trade mark is used in the course of trade for the goods or services which are not similar, but has reputation in Bangladesh and the use of the mark by the person without due cause, takes unfair advantage of or is detrimental to the distinctive character or repute of the registered trade mark.

3. Where a person who is not being duly authorized by the registered proprietor or a registered user uses the trade mark on a material intended to be used, for labeling or packaging goods, as business papers or for advertising goods or services.

4. Where a person not being a 'registered proprietor' or 'permitted user' uses a registered well-known trademark for the identical or similar goods or services for which the mark has been registered.

5. Where a person not being a 'registered proprietor' or 'permitted user' uses a registered well-known trademark for the goods or services not being identical with or similar to those in respect of which the mark has been registered, by using of the mark in relation to those goods or services, would indicate a connection between those goods or services and the owner of the registered well-known mark and that the interests of the owner of the registered well-known mark are likely to be damaged by such use.

\section{Remedies}

In compliance with the Paris Convention and TRIPS Agreement Bangladesh provides both civil and criminal remedies for infringement of the right of a registered proprietor of a trademark, which are as follows:

\section{V.I Civil remedies}

The Trademarks Act states that infringement suits must be instituted before the appropriate District Court having jurisdiction. In the case of infringement suits, the trademark must be registered in Bangladesh as per Section 24(1) of the Act. The Act also provides for passing off actions for unregistered trademarks. The period of limitation for filing a suit for infringement of a trade mark is three years from the date of infringement. The relief which a court may grant in any suit for infringement and passing off:

(i) An injunction restraining further use of the infringing mark.

(ii) Damages or an account of profits.

(iii) An order for delivery-up of infringing labels and marks for destruction or erasure.

The plaintiff is entitled to the above relief both in an infringing and passing off action. Although civil remedies are available for both registered and unregistered trademarks, it can be extremely difficult to prove passing off actions and obtain relief for unregistered trademarks.

\section{V.II Criminal prosecution/ Remedies}

The following are criminal offences punishable under the Act, 2009:

- $\quad$ applying a false trademark so as to mislead consumers about the origin of the goods;

- counterfeiting a trademark without assent of the proprietor of the trademark;

- making or possessing any instrument for the purposing of counterfeiting a trademark;

- applying any false trade description to goods or services;

- applying false indication of country to goods or services as regards the place of production or manufacture of them; and

- $\quad$ selling, or exposing or possessing for sale or any purpose of trade or manufacture any goods bearing a false trade mark or description.

The punishment for above-mentioned is imprisonment for up to two years but not less than six months or a fine up to taka two lac but not less than fifty thousand, or both and for a second or subsequent conviction, imprisonment up to three years but not less than one year or fine up to taka three lac but not less than one lac, or both. The courts also have the power to set the prison term and the amount of any fine.

All the above mentioned offences shall be triable by the Metropolitan Magistrate or Magistrate of the first class.

\section{Recommendations}

Bangladesh always faces the lack of political stability from her birth. As a result desirable industrial development does not occur here. For a smooth industrial development political stability is a must and needs a better trademark protection. In order to strengthen the trade mark protection in Bangladesh, the Government has to take several steps which can make the Trademark Registry Office speedier and implement the present trademark laws more effectively. They are as follows: 
- $\quad$ There must set up a trade mark registry office in each Divisional City to scrutinize the trade mark related matters very swiftly and to assist the industrial development smoothly. Presently, in our country only two trade mark registry office; Head office in Dhaka and branch office in Chittagong. As a result, the citizens of other cities have to face problems.

- Online trademark application system should be introduced due to shortage of trade mark registry office.

- Trademark Journal must be published in the trade mark registry office website.

- The number of Deputy Registrars, other officers and employees must be increased; the number of application for trademark registration increases in every year but due to shortage of staff it takes around 3-4 years to get trademark registration (where it should take only 12 months as a result the investors are becoming frustrated).

- Carrying out regular training for officials at the trade mark registry office with a view maintaining the provisions of international agreements (Paris Convention and TRIPS Agreement) as regards trade mark protection.

- Trade Mark Protection Court should be primarily introduced in the Divisional Cities in order to quick disposal of suits for trademark infringements and passing off.

- Trademark Rules, 1963 should be replaced with a new one with a view to reflecting the changes that have taken place since enactment of the Trademarks Act, 2009. It is pertinent to mention that the 1963 Rules were passed to fulfill the lacunae and complementary to the provisions of the Trademark Act, 1940. Now it is 2012, where the 1963 Rules are very old to fulfill the demand of present trademark protection. Besides, under the 2009 Act, new provision of collective mark has been inserted but the procedure of registration of it has not been mentioned in the Act, 2009. The procedure of publication of trademark journal is not specified in the present law; it should be determined by the new rules. Different forms of trademark, service mark, certification mark or collective mark should be updated to maintain the consistency of the digital based society. So, the replacement of 1963 Rules with a new one is a must.

\section{Concluding Remarks}

Trademark is one kind of intellectual property; it is a private right. Trademark protection needs for industrial smooth development in a country. In Bangladesh, under the Trademarks Act, 2009, the provisions have been introduced for affording better protection to registered marks and well-known marks, whether registered or not. The law contains adequate standard provisions to deal with matters such as trademark protection of registered or unregistered marks, infringement and falsifications of them, proper remedies in compliance with TRIPS Agreement but due to administrative inefficiency, lack of awareness of the people and very old rules (Trademark Rules, 1963), it stands tough to implement the present law (Trademarks Act, 2009) and to ensure exclusive protection to the trade mark proprietors. By removing the present problems better trademark protection can be ensured which can draw the attention of entrepreneurs, home and abroad, and one day, Bangladesh can turn into an industrial developed country.

\section{References}

[1] Mohammad Monirul Azam, Intellectual Property WTO and Bangladesh (1 $1^{\text {st }}$ ed), (pp170-175), Dhaka: New Warsi Book Corporation, 2008

[2] W. R. Cornish, Intellectual property: Patents, Copyright, Trademarks and Allied Rights, (3 ${ }^{\text {rd }}$ ed),(pp 515-639), Sweet \& Maxwell: London, 1996

[3] M. Farani Manual of Trademarks, Merchandise Marks \& Patents \& Designs: Lahore Law Time Publications, Revised \& Enlarged Edition.

[4] The Agreement on Trade-Related Aspects of Intellectual Property Rights, 1994

[5] The Paris Convention for the Protection of Industrial Property of 1883 as revised on 1979

[6] The Trademark Act, 2009 and Rules 1963, www.bdlaws.govt.com

[7] Jayashree Watal, Intellectual Property Rights in the WTO and Developing Countries, (1 ${ }^{\text {st }}$ ed), ( pp 207-242), Oxford University Press: New Delhi, 2000

[8] WIPO, Background Reading Material on Intellectual Property, (pp145-186), WIPO Publication No. 659(E)., 1988 